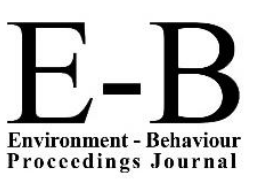

\title{
AicE-Bs2015Barcelona
}

$6^{\text {th }}$ Asia-Pacific International Conference on Environment-Behaviour Studies,

Barcelona School of Architecture (ETSAB), Barcelona, Spain,31 Aug.- 05 Sep. 2015

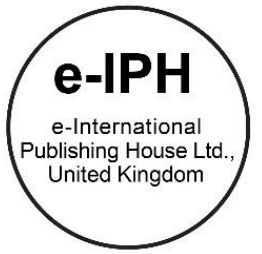

\section{Public Life of Small Towns Public Open Spaces in North Sumatra Province}

\author{
Achmad Delianur Nasution *, Wahyuni Zahrah \\ Department of Architecture, University of Sumatra Utara, Jl. Perpustakaan Ged.J.07 Kampus USU Medan 20155, Indonesia
}

\begin{abstract}
The urbanization process that change urban space and people also goes on in small towns in North Sumatra Province, Indonesia. As the region becomes more urbanized, commercial centers grow up. In contrast, public open space tends to decline. In this condition, the study aim is to explore the public life that goes on. The research indicates that almost POS was not designed based on common criteria of successful POS in those of developed countries. However, people utilize the POS intensively and meet people needs. The using grade of the POS shows that there is no a significant different between well-design and poor design POS.
\end{abstract}

(C) 2016. The Authors. Published for AMER ABRA by e-International Publishing House, Ltd., UK. Peer-review under responsibility of AMER (Association of Malaysian Environment-Behaviour Researchers), ABRA (Association of Behavioural Researchers on Asians) and cE-Bs (Centre for Environment-Behaviour Studies, Faculty of Architecture, Planning \& Surveying, Universiti Teknologi MARA, Malaysia.

Keywords: Public life; public open space; small towns; North Sumatra

\section{Introduction}

\subsection{Background}

The city life shows that many people do their activities in the public open spaces (POS), such as streets, pedestrian paths, parks and squares (Whyte, 1980, Gehl, 1996). Many scholars have proven the benefits of the activities, such as improving social cohesion, as well as physical and psychological health. Even, the unwell-planned public open space still gives a positive contribution to people quality of life (Nasution and Zahrah, 2014). The study about how people use POS relates to the quality of the POS (Karuppannan dan Asivan, 2013; Zakariya et al., 2014; Ngesan dan Zubir, 2015; Malek et al., 2015).

The development of many towns in Indonesia, particularly in North Sumatra province, tends to neglect the quality of POS, compared to the commercial districts with more attention in planning and design. In Medan, the capital city of North Sumatra province, the urban area becomes a display of malls, cafes, theme parks and gated communities (Nasution and Zahrah, 2012). The similar image, though not as 'dramatic' as Medan, is found in many small towns in North Sumatra province. The towns are characterized by commercial districts or corridors, with rows of dense shop-house, and street vendors in front of them. As people of big cities run the day with private vehicle, social media, and television reality shows, so do the small town's citizens. Among these conditions, how is the quality of the POS? Do people use it frequently? Does space meet their needs? What kind

* Corresponding author. Tel.: +62-819-870-170; fax: +62-61-8213250.

E-mail address: aan.nasution@gmail.com

(C) 2016. The Authors. Published for AMER ABRA by e-International Publishing House, Ltd., UK. Peer-review under responsibility of AMER (Association of Malaysian Environment-Behaviour Researchers), ABRA (Association of Behavioural Researchers on Asians) and cE-Bs (Centre for EnvironmentBehaviour Studies, Faculty of Architecture, Planning \& Surveying, Universiti Teknologi MARA, Malaysia. 
of needs? The research is meant to describe the public life in the small towns, particularly in a developing country like Indonesia, where the design of urban space has not been a favor.

\subsection{Objective}

The objective of the study is to explore the utilization of POS in small towns in North Sumatra province that configure public life. The study investigates the activities going on at POS, people who visit the place and the quality of facility and design relate to it. Moreover, the study also measures user satisfaction of POS to identify whether the place meets people needs. The exploration can describe the trend, similarity and difference of public open spaces in North Sumatra, particularly to compare them with those of capital city Medan. Thus, it can enrich the study of public life, particularly in the urban areas of developing country. It also can contribute to the local government to get a more suitable development for people condition and needs.

\section{Literature Review}

The study of public life means to take a look at how people use the urban space (Gehl, 1996). It can describe the changing of urban design related to the utilization, for example, what Gehl investigated in Copenhagen city center. A few years before Gehl's project, William H. Whyte (1980), carried out the study why and how urban space being utilized and 'life', meanwhile the others 'empty'. Refer to Gehl (1996), the successful public space characterized by the larger optional recreational activities than necessary activities. Moreover, people used it frequently (Jacobs, 2008) and involved a various social background of citizens (Whyte, 1980).

There are some aspects relate to the quality of POS, such as accessibility, facility, function/activity, management and climate comfort (PPS, 2000; Nasution and Zahrah, 2014). The good quality of POS will drive people to use it more intensively (Gehl, 1996; Whyte, 1980; Sakip et al., 2014). However, the premise does not apply to all places and cases. The study for neighborhood open space in Singapore, Delhi, and Kuala Lumpur that held by Karuppannan and Sivarn (2013) showed that the utilization of POS does not directly relate to its quality. The similar facts found in POS of Medan, North Sumatra, either in the urban-scale (Nasution and Zahrah, 2014) and neighborhood scale POS (Nasution and Zahrah, 2014).

The main difference POS of any place outside Indonesia, particularly in the developed country, is the POS are well planned and designed. In Indonesia, the design professionals - e.g. architect, landscape architect, urban designer - have not a proper role in designing urban space. Even, public place such as POS is not designed by the professional. This study tried to explore and investigate the quality of that kind of POS and how people used it.

\section{Methodology}

\subsection{Respondents}

The study took place in twelve small towns' POS in North Sumatra Province. They are Binjai, Stabat, Lubuk Pakam, Sei Rampah, Pematang Siantar, Brastagi, Batubara, Kisaran, Sipirok, Pandan, Sibolga, and Tarutung. The study area was the active urban-scale POS, showed by the activities occurred at those places. Most of the POS were the squares; two of the POS are a park and a river promenade. There were 781 respondents in the POS that interviewed. The surveyors chose them randomly at the activities zone.

\subsection{Variables and data collecting}

The study collected the data at the weekend on March 2015, while the utilization of POS reached the peak. The observation recorded the quality of the POS, such as the accessibility, the facility, the function and activity, the natural elements, and the management. Except the management factor, four of the five variables that indicate the quality of POS, are the elements of design. People who agreed to participate in the survey filled a set of questions guided by the surveyors. The questionnaire consisted of the questions about demographic background (age, gender, education, occupancy, and residential status) and the intensity of the utilization of POS (time of visits, duration, frequency, aim of visits, the activities). The field survey measured people perception based on the 5 points Likert scale, from 5 to 'very satisfied' to 1 'very unsatisfied'. The means score of each 
variable indicated the level of satisfaction. The average rating higher than 3 reflected the respondents were satisfied, and the lower than 3 showed that respondents were not satisfied.

\section{Result and Discussion}

\subsection{Study area}

North Sumatra province is a region that mostly rural. Agriculture and Plantation are the major economic income of the province. In the era of Dutch Colonial in Indonesia, there were just six autonomy towns, namely Medan, Binjai, Tebing Tinggi, Pematang Siantar, Tanjung Balai, and Sibolga. The other towns are the Kecamatan-towns as the capitals of the regencies. When the government applied autonomy regulation since 1999, the new regencies with the new urbanized areas have been rising. Those areas characterized by the denser commercials districts. Now there are 33 regencies and towns with more than 12 million people in this province. The towns and regency-towns have less than 300.000 populations.

Most of the urban-scale POS in the province are the squares, as the typical features of the government complex since the Dutch era. The squares become the center of the government and public facility buildings around them. The city hall, great mosque, and town/regency parliament houses are some of the typical buildings around the square. The square becomes the place of the official nation-ceremonies, such as Independence Day and the National Hero Day. However, the daily function of the squares is the public area where people socialize, exercise and play.

\subsection{Respondents characteristics}

There were 836 respondents participated in the survey. They were mostly the local residence, youth of $16-20$ years old, and students. The male is larger (55.70 \%) than female (44.30\%) (Table 1).

Table 1. Respondent characteristics (in percent)

\begin{tabular}{|c|c|c|c|c|c|c|c|c|c|c|c|c|}
\hline \multirow[b]{2}{*}{ Variable } & \multicolumn{12}{|c|}{ Public Open Space } \\
\hline & Bat & Bra & Bin & Kis & Lub & Pan & Pem & Sip & Sta & Tar & Sib & Ram \\
\hline Number & 68 & 70 & 70 & 70 & 70 & 70 & 70 & 89 & 70 & 70 & 44 & 30 \\
\hline Residence & $\begin{array}{c}86,8 \\
0\end{array}$ & $\begin{array}{c}84,3 \\
0\end{array}$ & 71,4 & 75,7 & 66,7 & 72,3 & 80 & 61,8 & 45,7 & 49,3 & 74,4 & 60 \\
\hline Female & $\begin{array}{c}30,9 \\
0\end{array}$ & 28,6 & 55,7 & 38,6 & 24,3 & 58,8 & 71,4 & 52,8 & 42,9 & 45,1 & 47,7 & 36,7 \\
\hline Male & $\begin{array}{c}69,1 \\
0\end{array}$ & 71,4 & 44,3 & ,61,4 & 75,7 & 41,2 & 28,6 & 47,2 & 57,1 & 54,9 & 52,3 & 63,3 \\
\hline Age & $\begin{array}{c}31- \\
35 \\
16,2\end{array}$ & $\begin{array}{c}16- \\
20 \\
41,4\end{array}$ & $\begin{array}{c}16- \\
20 \\
38,6\end{array}$ & $\begin{array}{c}16- \\
20 \\
37,1\end{array}$ & $\begin{array}{c}16- \\
20 \\
40,6\end{array}$ & $\begin{array}{c}16- \\
20 \\
38,0\end{array}$ & $\begin{array}{c}16- \\
20 \\
50,0\end{array}$ & $\begin{array}{c}16- \\
20 \\
80,9\end{array}$ & $\begin{array}{c}16- \\
20 \\
47,1\end{array}$ & $\begin{array}{c}16- \\
20 \\
32,9\end{array}$ & $\begin{array}{c}16- \\
20 \\
34,1\end{array}$ & $\begin{array}{c}16- \\
20 \\
36,7\end{array}$ \\
\hline
\end{tabular}

Note:

$$
\begin{aligned}
& \text { Bat }=\text { Batubara } \\
& \text { Bra = Brastagi } \\
& \text { Bin= Binjai } \\
& \text { Kis = Kisaran }
\end{aligned}
$$

$$
\begin{aligned}
& \text { Lub = Lubuk Pakam } \\
& \text { Pan = Pandan } \\
& \text { Pem = Pematang Siantar } \\
& \text { Sip = Sipirok }
\end{aligned}
$$

\subsection{Quality of POS}

\subsubsection{Facility}

Most of POS were squares with typical rectangular form and facilities. The squares were grass field, with a pendopo (a kind of permanent open stage) for the official ceremonies purpose. The other facilities took place in one part of the squares, e.g. one of the corners, consisted of the seating area, pedestrian path/jogging track, children playground/tot lot, garden, and trees. There 
were street vendors in almost all squares, they usually sole foods and toys. Less than half of the squares had a complete facilities (Binjai, Sipirok, Stabat, Sibolga), such as the basketball and badminton fields, fitness/exercise instruments, and tot lots. The POS in Brastagi, Pandan, Rampah and Tarutung had the poorest facilities and design (Table 2). The other POS had some facilities but had a lack management and maintenance. The dirty - leak - lack - facilities were the common condition at those places. Brastagi and Rampah, for example, only had a poor maintenance grass field and seating area. Except the two POS (mean score lower than 3), the satisfaction level with the facilities were fair, with mean score 3 or more, but not reach 4 . The highest satisfaction level found in Stabat (mean score 3.5), although the facilities were less good than Kisaran, Binjai and Sipirok (Table 3).

Table 2. POS facilities

\begin{tabular}{|c|c|c|c|c|c|c|c|c|c|c|c|c|c|c|}
\hline \multirow[t]{2}{*}{ POS } & \multicolumn{13}{|c|}{ POS Facilities } & \multirow[t]{2}{*}{ Des } \\
\hline & Par & Toi & Grf & Ped & Ben & Ost & Exe & Bas & Tot & Stv & Mos & Gar & Tre & \\
\hline Bat & - & $\sqrt{ }$ & $\sqrt{ }$ & $\sqrt{ }$ & $\sqrt{ }$ & $\sqrt{ }$ & - & - & - & $\sqrt{ }$ & $\sqrt{ }$ & $\sqrt{ }$ & $\sqrt{ }$ & Fair \\
\hline $\mathrm{Bra}$ & - & $\sqrt{ }$ & $\sqrt{ }$ & - & $\sqrt{ }$ & $\sqrt{ }$ & - & - & - & $\sqrt{ }$ & & & $\sqrt{ }$ & Poor \\
\hline Bin & $\sqrt{ }$ & $\sqrt{ }$ & $\sqrt{ }$ & $\sqrt{ }$ & $\sqrt{ }$ & $\sqrt{ }$ & - & $\sqrt{ }$ & $\sqrt{ }$ & $\sqrt{ }$ & $\sqrt{ }$ & $\sqrt{ }$ & $\sqrt{ }$ & Fair \\
\hline Kis & $\sqrt{ }$ & $\sqrt{ }$ & $\sqrt{ }$ & $\sqrt{ }$ & $\sqrt{ }$ & $\sqrt{ }$ & $\sqrt{ }$ & $\sqrt{ }$ & - & - & - & $\sqrt{ }$ & $\sqrt{ }$ & Good \\
\hline Lub & - & $\sqrt{ }$ & $\sqrt{ }$ & $\sqrt{ }$ & $\sqrt{ }$ & $\sqrt{ }$ & $\sqrt{ }$ & - & - & - & - & $\sqrt{ }$ & $\sqrt{ }$ & Poor \\
\hline Pan & $\sqrt{ }$ & $\sqrt{ }$ & $\sqrt{ }$ & - & - & $\sqrt{ }$ & - & - & - & $\sqrt{ }$ & - & - & $\sqrt{ }$ & Poor \\
\hline Pem & - & $\sqrt{ }$ & $\sqrt{ }$ & $\sqrt{ }$ & $\sqrt{ }$ & - & - & - & - & $\sqrt{ }$ & $\sqrt{ }$ & $\sqrt{ }$ & $\sqrt{ }$ & Poor \\
\hline Sip & $\sqrt{ }$ & $\sqrt{ }$ & $\sqrt{ }$ & $\sqrt{ }$ & $\sqrt{ }$ & - & - & $\sqrt{ }$ & $\sqrt{ }$ & $\sqrt{ }$ & & $\sqrt{ }$ & $\sqrt{ }$ & Good \\
\hline Sta & $\sqrt{ }$ & $\sqrt{ }$ & $\sqrt{ }$ & $\sqrt{ }$ & $\sqrt{ }$ & $\sqrt{ }$ & - & - & $\sqrt{ }$ & $\sqrt{ }$ & $\sqrt{ }$ & $\sqrt{ }$ & $\sqrt{ }$ & Fair \\
\hline Tar & - & - & - & $\sqrt{ }$ & $\sqrt{ }$ & - & - & - & - & $\sqrt{ }$ & - & $\sqrt{ }$ & $\sqrt{ }$ & Poor \\
\hline Sib & - & $\sqrt{ }$ & $\sqrt{ }$ & $\sqrt{ }$ & $\sqrt{ }$ & $\sqrt{ }$ & $\sqrt{ }$ & $\sqrt{ }$ & $\sqrt{ }$ & $\sqrt{ }$ & - & $\sqrt{ }$ & $\sqrt{ }$ & Fair \\
\hline Ramp & - & $\sqrt{ }$ & $\sqrt{ }$ & $\sqrt{ }$ & - & - & - & - & - & $\sqrt{ }$ & - & - & $\sqrt{ }$ & Poor \\
\hline \multicolumn{5}{|c|}{$\begin{array}{l}\text { Par }=\text { Parking lot } \\
\text { Toi }=\text { Toilet } \\
\text { Grf }=\text { Grass field } \\
\text { Ped }=\text { Pedestrian path } \\
\text { Ben = Bench/ outdoor seating }\end{array}$} & \multicolumn{5}{|c|}{$\begin{array}{l}\text { Ost }=\text { Open stage } / \text { pendopo } \\
\text { Exe }=\text { Exercise/fitness instrument } \\
\text { Bas }=\text { Basketball Arena } \\
\text { Tot }=\text { Tot lot } \\
\text { Stv }=\text { Street vendor }\end{array}$} & & \multicolumn{3}{|c|}{$\begin{array}{l}\text { Mos }=\text { Mosque } \\
\text { Gar }=\text { Garden } \\
\text { Tre = Trees } \\
\text { Des }=\text { Design quality }\end{array}$} & \\
\hline
\end{tabular}

Table 3. Mean score of people satisfaction with POS facilities

\begin{tabular}{|c|c|c|c|c|c|c|c|c|c|c|c|c|c|}
\hline \multirow[t]{2}{*}{ Variable } & \multicolumn{13}{|c|}{ Public Open Space } \\
\hline & Bat & Bra & Bin & Kis & Lub & Pan & Pem & Sip & Sta & Tar & Sib & Ram & Aver. \\
\hline Dimension/widht & 3,88 & 3,70 & 3,27 & 4,00 & 4,06 & 3,75 & 3,60 & 3,67 & 3,86 & 3,26 & 4,25 & 3,57 & 3,74 \\
\hline Parking lot & 3,50 & 2,61 & 2,87 & 3,84 & 3,31 & 3,40 & 2,99 & 3,44 & 3,56 & 3,07 & 3,84 & 2,47 & 3,27 \\
\hline Pedestrian path & 3,63 & 2,77 & 3,43 & 3,81 & 3,61 & 3,44 & 3,50 & 3,42 & 3,54 & 3,10 & 4,32 & 3,30 & 3,49 \\
\hline Toilet & 3,28 & 1,77 & 2,17 & 2,30 & 2,03 & 3,07 & 2,14 & 2,90 & 2,07 & 2,47 & 2,14 & 2,00 & 2,41 \\
\hline Playing area & 3,65 & 3,33 & 3,24 & 3,20 & 3,61 & 3,59 & 3,27 & 3,54 & 3,66 & 2,81 & 4,09 & 2,53 & 3,38 \\
\hline Sport/exer. Area & 3,79 & 3,77 & 3,46 & 3,73 & 3,73 & 3,69 & 3,29 & 3,33 & 3,64 & 2,99 & 4,23 & 4,03 & 3,65 \\
\hline Sitting area & 3,90 & 3,21 & 3,46 & 3,54 & 3,76 & 3,85 & 3,61 & 3,63 & 3,54 & 3,53 & 3,39 & 3,93 & 3,62 \\
\hline Garden area & 3,72 & 2,94 & 3,31 & 3,64 & 3,79 & 3,71 & 3,60 & 3,76 & 3,63 & 3,11 & 3,28 & 2,50 & 3,43 \\
\hline Picnic area & 3,43 & 2,60 & 2,94 & 2,90 & 3,36 & 3,46 & 3,24 & 3,63 & 3,36 & 2,73 & 2,75 & 2,07 & 3,06 \\
\hline Mosque/praying & 3,84 & 2,60 & 3,39 & 2,71 & 3,09 & 3,39 & 2,46 & 3,36 & 3,57 & 3,21 & 2,64 & 2,00 & 3,05 \\
\hline
\end{tabular}


Nasution, A.D., \& Zahrah, W., / $6^{\text {th }}$ AicE-Bs2015Barcelona, Spain, 30 Aug.- 04 Sep. 2015 / E-BPJ, Maiden Issue, 1(1) June 2016 (pp.375-383)

\begin{tabular}{|c|c|c|c|c|c|c|c|c|c|c|c|c|c|}
\hline area & & & & & & & & & & & & & \\
\hline Dining area & 3,63 & 3,20 & 3,36 & 2,16 & 3,23 & 3,37 & 3,39 & 3,16 & 3,84 & 3,40 & 4,05 & 3,63 & 3,36 \\
\hline Street vendor & 3,47 & 2,86 & 3,01 & 3,57 & 3,04 & 3,40 & 3,00 & 2,69 & 3,71 & 3,24 & 4,16 & 3,83 & 3,34 \\
\hline Average & 3,64 & 2,95 & 3,16 & 3,28 & 3,39 & 3,51 & 3,17 & 3,38 & 3,50 & 3,08 & 3,60 & 2,99 & 3,32 \\
\hline
\end{tabular}

\subsubsection{Accessibility}

Most of the POS had no good accessibility, due to the absence of pedestrian linkage and public transport integration (Project for Public Spaces, 2000; Gehl 2002; CABE dan DETR, 2001). The only good aspect of accessibility was the clear gates. There was no controlling or filtering of the visitors. The POS was mainly a typical square with roads surrounded. Thus, the place seemed like an 'alienated island'. However, the POS were not so hard to be reached due to the not so busy traffic, at least if it compared with Medan (Nasution and Zahrah, 2014). With these conditions, all aspects of accessibility were generally perceived at a good level (the satisfaction level more than 3, though the satisfaction level did not reach 4 . The fact related to the people's circulation habit that more preferred private vehicle (primarily motorcycle) than walking or public transport, even though the distance from home was less than 500 meters. Only two POS (Brastagi and Pematang Siantar) that the majority of visitors came to the POS by walk (Table 4). Since most of the respondents used the motorcycle to get to the POS, there were no problems with the distance. Though many respondents lived more than $5 \mathrm{~km}$ from POS, they were generally satisfied with the accessibility aspects, including distance (Table 5). The fact was similar with capital city Medan (Nasution dan Zahrah, 2013), so it can be said that motorcycling is one of people's fashion in North Sumatra region. The reality is different with the nature of many POS in other places, particularly those of developed countries. In those cases, the POS are good quality if having the good pedestrian linkage.

Table 4. Vehicle ownership, transportation mode and POS distance from home

\begin{tabular}{|c|c|c|c|c|c|c|c|c|c|c|c|c|c|}
\hline \multirow[t]{2}{*}{ Variable } & \multicolumn{13}{|c|}{ Public Open Space } \\
\hline & Bat & Bra & Bin & Kis & Lub & Pan & Pem & Sip & Sta & Tar & Sib & Tan & Ram \\
\hline private & mot & no & mot & mot & mot & mot & no & no & mot & mot & no & mot & mot \\
\hline vehicle & 61,2 & 57,1 & 64,3 & 59,7 & 53,6 & 43,9 & 57,1 & 545 & 57,1 & 50,0 & 409 & 48,9 & 46,7 \\
\hline \multicolumn{14}{|l|}{ ownership } \\
\hline \multirow{2}{*}{$\begin{array}{l}\text { Transportat } \\
\text { ion mode }\end{array}$} & mot & wal & mot & mot & mot & mot & wal & mot & mot & mot & mot & mot & mot \\
\hline & 52,3 & 61,4 & 51,4 & 64,3 & 48,6 & 50,7 & 38,6 & 51,7 & 67,1 & 52,9 & 45,5 & 38,6 & 22,7 \\
\hline \multirow[t]{3}{*}{ Distance } & $<$ & $<$ & $>5$ & $3-5$ & $0.5-1$ & $<$ & $>5$ & $>5$ & $>5$ & $>5$ & $3-5$ & $1-3$ & $0.5-$ \\
\hline & 500 & 500 & $\mathrm{~km}$ & $\mathrm{~km}$ & $\mathrm{~km}$ & 500 & $\mathrm{~km}$ & $\mathrm{~km}$ & $\mathrm{~km}$ & $\mathrm{~km}$ & $\mathrm{~km}$ & $\mathrm{~km}$ & $1 \mathrm{~km}$ \\
\hline & $\underset{35,3}{m}$ & $\underset{45,7}{m}$ & 34,8 & 35,7 & 50,7 & $\begin{array}{c}\mathrm{m} \\
35,3\end{array}$ & 30,0 & 47,7 & 37,1 & 28,6 & 36,4 & 43,2 & 30,0 \\
\hline
\end{tabular}

Mot $=$ motor cycle

No $=$ no private vehicle

Wal = walking

Table 5. Mean score of people satisfaction with POS accessibility

\begin{tabular}{|c|c|c|c|c|c|c|c|c|c|c|c|c|c|c|}
\hline \multirow[t]{2}{*}{ Variable } & \multicolumn{14}{|c|}{ Public Open Space } \\
\hline & Bat & $\mathrm{Bra}$ & Bin & Kis & Lub & Pan & $\begin{array}{c}\mathrm{Pe} \\
\mathrm{m}\end{array}$ & Sip & Sta & Tar & Sib & Tan & Ram & Aver. \\
\hline Distance & $\begin{array}{c}3,6 \\
5\end{array}$ & $\begin{array}{c}3,2 \\
1\end{array}$ & $\begin{array}{c}3,3 \\
4\end{array}$ & $\begin{array}{c}3,3 \\
4\end{array}$ & $\begin{array}{c}3,5 \\
4\end{array}$ & $\begin{array}{c}3,3 \\
4\end{array}$ & $\begin{array}{c}3,3 \\
6\end{array}$ & $\begin{array}{c}3,1 \\
2\end{array}$ & $\begin{array}{c}3,2 \\
0\end{array}$ & $\begin{array}{c}3,2 \\
4\end{array}$ & $\begin{array}{c}3,7 \\
7\end{array}$ & $\begin{array}{c}3,6 \\
4\end{array}$ & 3,03 & 3,37 \\
\hline Easy entering & $\begin{array}{c}3,7 \\
6\end{array}$ & $\begin{array}{c}3,4 \\
9\end{array}$ & $\begin{array}{c}3,7 \\
9\end{array}$ & $\begin{array}{c}3,7 \\
9\end{array}$ & $\begin{array}{c}3,6 \\
5\end{array}$ & $\begin{array}{c}3,5 \\
7\end{array}$ & $\begin{array}{c}3,6 \\
7\end{array}$ & $\begin{array}{c}3,3 \\
4\end{array}$ & $\begin{array}{c}3,8 \\
1\end{array}$ & $\begin{array}{c}3,3 \\
6\end{array}$ & $\begin{array}{c}4,1 \\
4\end{array}$ & $\begin{array}{c}3,8 \\
9\end{array}$ & 3,83 & 3,70 \\
\hline $\begin{array}{c}\text { Transportatio } \\
n\end{array}$ & $\begin{array}{c}3,7 \\
3\end{array}$ & $\begin{array}{c}3,4 \\
7\end{array}$ & $\begin{array}{c}3,7 \\
9\end{array}$ & $\begin{array}{c}3,7 \\
0\end{array}$ & $\begin{array}{c}3,5 \\
4\end{array}$ & $\begin{array}{c}3,4 \\
7\end{array}$ & $\begin{array}{c}3,7 \\
6\end{array}$ & $\begin{array}{c}3,4 \\
7\end{array}$ & $\begin{array}{c}3,5 \\
7\end{array}$ & $\begin{array}{c}3,3 \\
0\end{array}$ & $\begin{array}{c}4,0 \\
2\end{array}$ & $\begin{array}{c}3,6 \\
2\end{array}$ & 3,73 & 3,63 \\
\hline Traffic & $\begin{array}{c}3,4 \\
9\end{array}$ & $\begin{array}{c}3,5 \\
3\end{array}$ & $\begin{array}{c}3,5 \\
4\end{array}$ & $\begin{array}{c}3,7 \\
0\end{array}$ & $\begin{array}{c}3,6 \\
4\end{array}$ & $\begin{array}{c}3,3 \\
1\end{array}$ & $\begin{array}{c}3,9 \\
6\end{array}$ & $\begin{array}{c}3,7 \\
2\end{array}$ & $\begin{array}{c}3,8 \\
1\end{array}$ & $\begin{array}{c}3,2 \\
7\end{array}$ & $\begin{array}{c}4,0 \\
0\end{array}$ & $\begin{array}{c}3,7 \\
7\end{array}$ & 3,63 & 3,64 \\
\hline
\end{tabular}




\begin{tabular}{|c|c|c|c|c|c|c|c|c|c|c|c|c|c|c|}
\hline Average & & & & & & & & & & & & & & \\
\hline & $\begin{array}{l}3.6 \\
a^{6}\end{array}$ & $\begin{array}{c}3.4 \\
3\end{array}$ & $\begin{array}{c}3.6 \\
2\end{array}$ & $\begin{array}{c}3.6 \\
3\end{array}$ & $\begin{array}{c}3.5 \\
9\end{array}$ & $\begin{array}{l}3.4 \\
2 \mathrm{~b}\end{array}$ & $\begin{array}{c}3.6 \\
9\end{array}$ & $\begin{array}{c}3.4 \\
1\end{array}$ & $\begin{array}{c}3.6 \\
0\end{array}$ & $\begin{array}{c}3.2 \\
9\end{array}$ & $\begin{array}{c}3.9 \\
8\end{array}$ & $\begin{array}{c}3.7 \\
3\end{array}$ & 3.56 & 3.59 \\
\hline
\end{tabular}

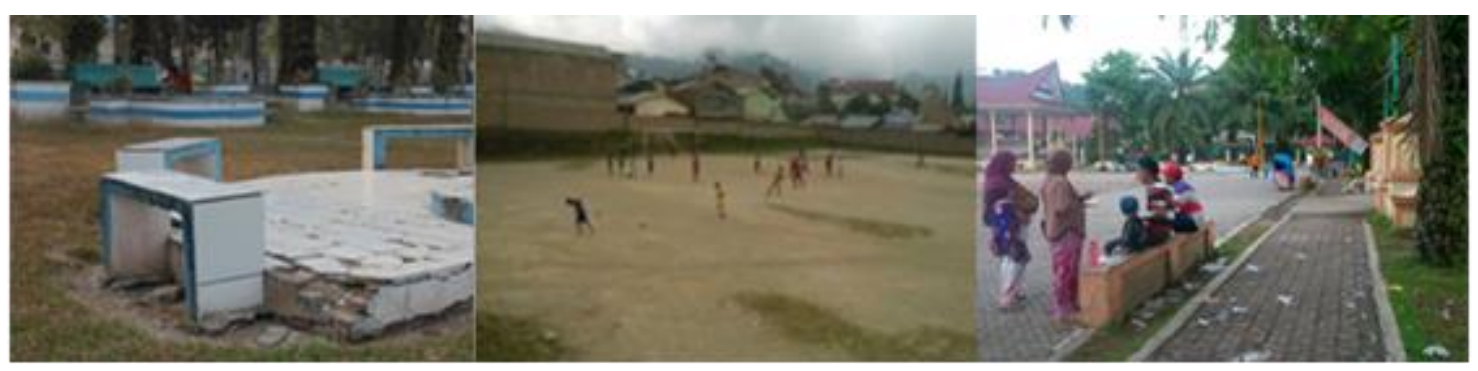

Fig. 1. Some of poor design and maintenance facilities in (a) Lubuk Pakam (b) Brastagi (c) Sibolga

\subsubsection{Climate comfort}

The climate comfort relates to the presence of trees, garden, and the sun heat and rain protector. One of the features that fill almost the POS is trees and grass field. The natural elements were arranged along the POS periphery. There were some trees in the seating area of some POS. Thus, they shadowed the area below from sun heat. However, at some POS the trees did not meet people needs, because of the number, distribution, and the quality. The people satisfaction level of this features were below 3 in Batubara, Brastagi, Tarutung, and Sibolga. However the rest were perceived good, but the mean scores were below 4. The satisfaction level for rain protector is the lowest, since, except pendopo, there was no construction with canopy in almost all the POS.

Table 6. Mean score of people satisfaction with climate comfort

\begin{tabular}{ccccccccccccccc}
\hline & Bat & Bra & Bin & Kis & Lub & Pan & Pem & Sip & Sta & Tar & Sib & Tan & Ram & Aver. \\
\hline Trees & 2,69 & 2,66 & 3,49 & 3,24 & 4,01 & 3,04 & 4,03 & 3,98 & 3,86 & 2,99 & 2,36 & 3,76 & 3,47 & 3,35 \\
\hline $\begin{array}{c}\text { Wind } \\
\text { velocity }\end{array}$ & 3,50 & 3,24 & 3,64 & 3,73 & 3,64 & 3,57 & 3,99 & 4,13 & 3,79 & 3,33 & 3,57 & 3,75 & 3,70 & 3,66 \\
\hline $\begin{array}{c}\text { Sun- } \\
\text { shading }\end{array}$ & 2,81 & 2,27 & 3,19 & 2,70 & 3,43 & 3,06 & 3,75 & 3,78 & 3,24 & 3,23 & 1,95 & 3,75 & 3,53 & 3,13 \\
\hline $\begin{array}{c}\text { Rain } \\
\text { protecting }\end{array}$ & 2,97 & 2,16 & 2,77 & 2,37 & 3,03 & 3,29 & 2,96 & 3,48 & 2,83 & 3,20 & 2,12 & 3,48 & 3,57 & 2,94 \\
\hline Average & 2,99 & 2,58 & 3,27 & 3,01 & 3,53 & 3,24 & 3,68 & 3,84 & 3,43 & 3,19 & 2,50 & 3,57 & 3,27 & 2,99 \\
\hline
\end{tabular}

\subsection{Public life}

The people came to the POS were variable in age, but most of them were teenagers. They came to the POS in a group, indicated that they were socializing. The people utilized POS frequently, mainly 1-3 times a week, and stayed there for 1-2 hours. The facts were similar with capital city Medan (Nasution and Zahrah, 2014). However, not like Medan, the utilization of the POS was going on until night. Kids and teenagers still utilize POS for various activities, such as playing or just sitting in a group with friends. It can be said that from the duration of using, the POS in the small towns was more intensively used. The most activities going on in the POS was sport/exercising, such as jogging, walking, aerobic gymnastic, fitness, cycling. People also played various game-sports, such as football, basketball, volleyball, badminton, roller skate and the skateboard. However, there were 
not always the adequate facilities for such games. Grass field became a multi-purpose ground for many kinds of games, but pendopo also became the arena for skateboard, roller blade and badminton (Table 7).

The other popular activity was sitting. Most of the POS had the facility, except Rampah and Pandan. People sat everywhere they could sit; not just on the seating equipment, but also on the grass field, pendopo steps, the garden or pedestrian path barrier, even on the motorcycle. In Stabat, the moveable chair was part of street vendors' equipment. Since there was a large number street vendors'chairs and utilized by many visitors, it became the main facilities at the square. The fact, it gave contribution in supporting public life in the POS.

Besides teenagers, the most visitors of POS were children. They came to the POS did not always relate to the presence of tot lot. Rampah and Brastagi, which had no children playground and its equipment, still utilized by children. The fact indicated that the activity in the POS did not always directly relate to the quality (Karuppannan dan Sivarn, 2013; Nasution and Zahrah, 2013, 2014). POS Kisaran, for example, had a complete facility with good design, but the place was not more utilized compared to fairdesign POS like Stabat and Pematang Siantar.

In average, people generally satisfied with function and activities of POS, even the poor quality POS in Rampah and Brastagi, which had a lower satisfaction level for facilities. The fact showed that people felt that the POS met their needs, though it had not reached an optimal level. The highest satisfaction level was for sport and socializing function, and the lowest was politics and democracy function (Table 8)

Table 7. Activities at POS

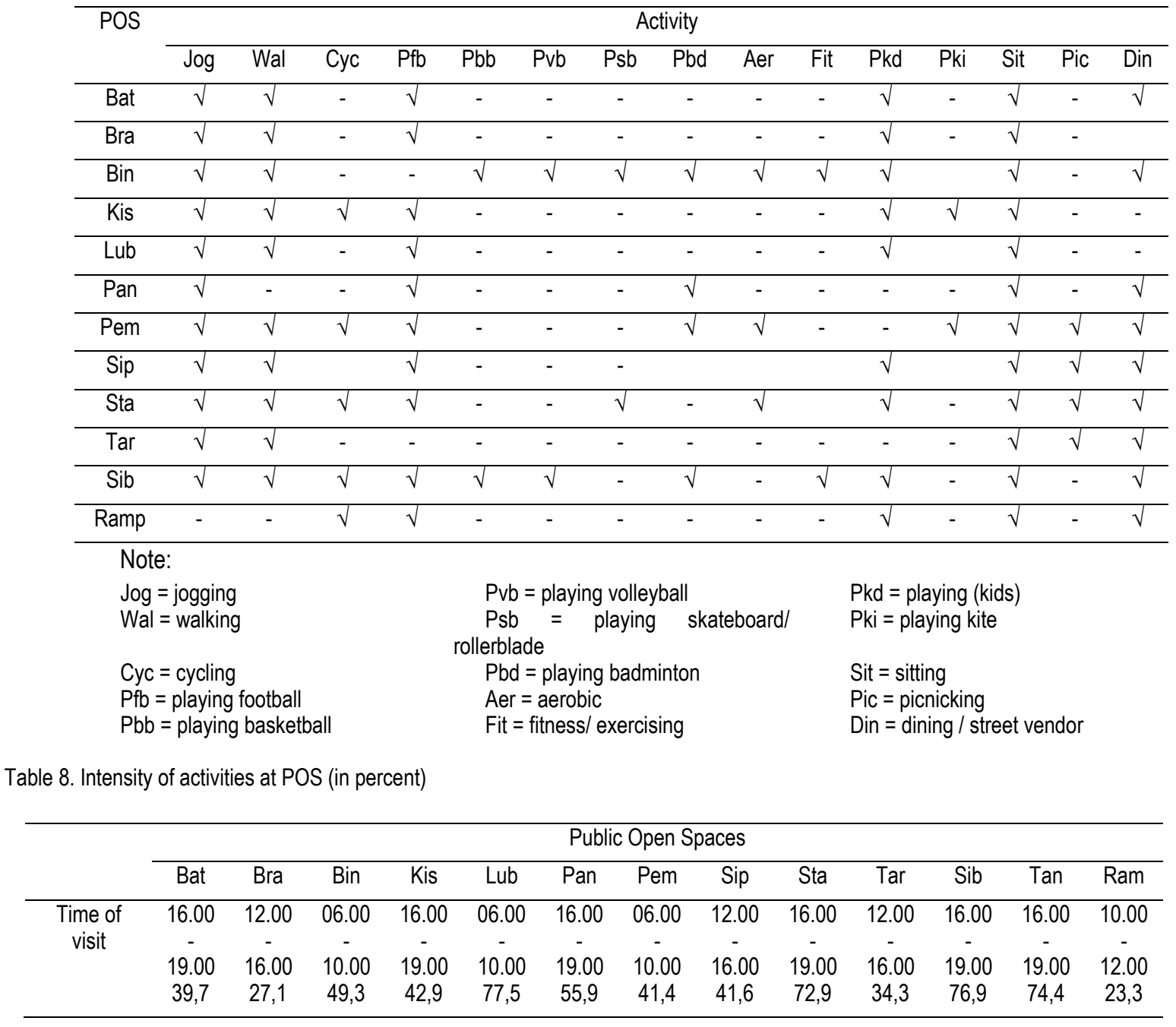

Table 8. Intensity of activities at POS (in percent) 
Nasution, A.D., \& Zahrah, W., / 6 th AicE-Bs2015Barcelona, Spain, 30 Aug.- 04 Sep. 2015 / E-BPJ, Maiden Issue, 1(1) June 2016 (pp.375-383)

\begin{tabular}{cccccccccccccc}
\hline $\begin{array}{c}\text { Duration of } \\
\text { visits }\end{array}$ & $1-2$ & $1-2$ & $1-2$ & $1-2$ & $1-2$ & $1-2$ & $1-2$ & $1-2$ & $1-2$ & $1-2$ & $>2$ & $1-2$ & $1-2$ \\
(hour) & & & & & & & & & & & & & \\
\hline $\begin{array}{c}\text { Freq. of } \\
\text { visits }\end{array}$ & $1-3$ & $1-3$ & $1-3$ & $1-3$ & $1-3$ & $1-3$ & $1-3$ & $1-3$ & $1-3$ & $1-3$ & $1-3$ & $1-3$ & $>3$ \\
ter wes & times & times & times & times & times & times & times & times & times & times & times & times \\
(per) & 46,3 & 50 & 65,7 & 58,6 & 52,9 & 61,8 & 52,2 & 67,4 & 68,6 & 68,6 & 50,0 & 50,0 & 46,7 \\
\hline $\begin{array}{c}\text { Aim of } \\
\text { visits }\end{array}$ & Sport & Sport & Sport & Sport & Sport & relax & Sport & Ff & Ff & Ff & Sport & Sport & Sport \\
& lexer & lexer & lexer & lexer & lexer & 32,8 & lexer & gath & gath & gath & lexer & lexer & exerc \\
& 53,8 & 68,6 & 40,3 & 64,2 & 80,6 & & 33,3 & 33,3 & 41,8 & 60,3 & 56,8 & 38,6 & 33,3 \\
\hline $\begin{array}{c}\text { Activity in } \\
\text { the }\end{array}$ & POS & POS & POS & POS & POS & natur & natur & natur & POS & POS & POS & Cafe. & POS \\
weekend & 51,5 & 52,9 & 38,9 & 47,8 & 44,3 & 41,4 & 31,9 & 37,1 & 52,9 & 47,8 & 61,4 & 52,3 & 36,7 \\
\hline
\end{tabular}

Note:

exe = exercising Relax $=$ relaxing Nature $=$ natural tourism $\quad$ Ff gath $=$ Family $/$ friend gathering

Table 9. Mean score of people satisfaction with POS function/activity

\begin{tabular}{lllllllllllllll}
\hline & Bat & Bra & Bin & Kis & Lub & Pan & Pem & Sip & Sta & Tar & Sib & Tan & Ram & Aver. \\
\hline Recreation & 3,52 & 2,96 & 3,31 & 3,57 & 3,40 & 3,40 & 3,24 & 3,70 & 3,61 & 3,17 & 2,93 & 3,40 & 2,75 & 3,30 \\
\hline Sport/exercise & 3,91 & 4,04 & 3,51 & 3,96 & 3,96 & 3,69 & 3,47 & 3,48 & 3,73 & 3,14 & 4,09 & 3,77 & 3,77 & 3,73 \\
\hline Socialization & 3,72 & 3,39 & 3,51 & 3,66 & 3,61 & 3,49 & 3,56 & 3,53 & 3,76 & 3,23 & 3,98 & 3,70 & 4,07 & 3,63 \\
\hline Politic & 3,31 & 3,03 & 2,99 & 2,96 & 2,99 & 3,21 & 2,77 & 3,33 & 3,21 & 3,10 & 2,95 & 2,41 & 2,97 & 3,02 \\
\hline Average & 3.62 & 3.36 & 3.33 & 3.54 & 3.49 & 3.45 & 3.26 & 3.51 & 3.58 & 3.16 & 3.49 & 3.32 & 3.39 & 3.42 \\
\hline
\end{tabular}
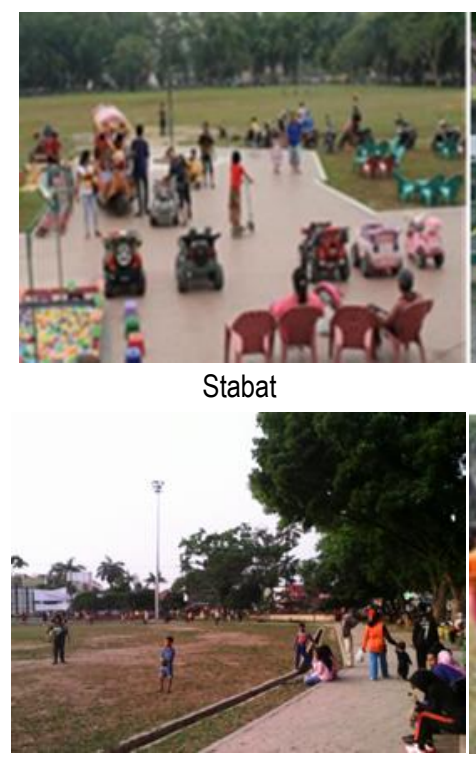

Binjai

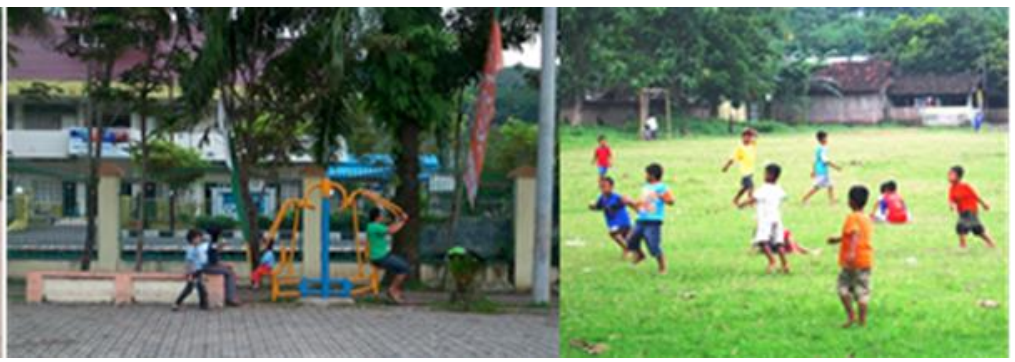

Sibolga

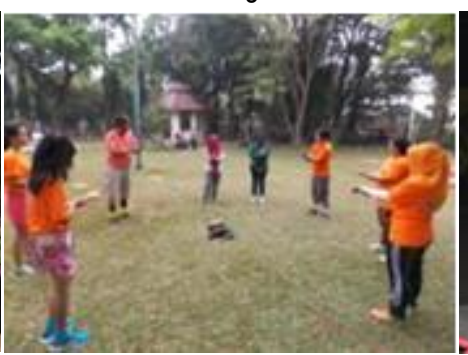

Pematang Siantar

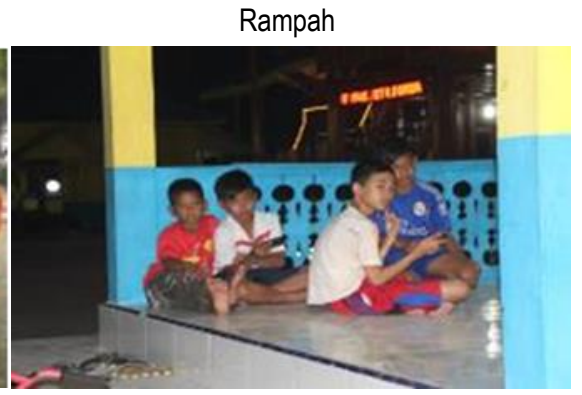

Batubara 
Fig. 2. Some of public life

\section{Conclusion}

The result of the study shows that public life in small towns' POS of North Sumatra province was going on intensively, with or without an adequate quality of design, facility, and management. It is similar with Medan, where they have no many choices for free access place in the city. The research confirms several similar studies ( Karuppannan and Sivam, 2013, Nasution and Zahrah, 2013, 2014). The researchs found that quality of POS was not always equal to its utilization. The phenomenon particularly found in cities of developing country like Indonesia, where there is limited choice. However, with the fair satisfaction level, the quality of POS has to be enhanced. It is necessary for the government to place the POS as one of the development priority. The future step recommends the deeper analysis in formulating the quality of POS that more suitable for local people needs.

\section{Acknowledgements}

This research was supported by Ministry of National Education of Indonesian Republic through Hibah Bersaing research grant. Thank you for all surveyors and participants for their precious contributions.

\section{References}

Gehl, J., \& Gemzoe, L. (1996). Public Spaces - Public Life. The Danish Architectural Press, And The Royal Danish Academy of Fine Arts, School of Architecture Publishers. Copenhagen

Harun, N. Z., Zakarya, K., Mansor, M., \& Zakaria, K. (2014). Determining attributes of urban plaza for social sustainability. Procedia - Social and Behavioral Sciences 153 (2014) 606-615.

Ismail, W. A. W., \& Said, I. (2015). Integrating the community in urban design and planning of public spaces: a review in malaysian cities. Procedia - Social and Behavioral Sciences 170 (2015) 357.364.

Jacobs, Jane, (1961) The Death And Life of Great American Cities, New York: Random House

Jurkovic, N. B. (2014). Perception, experience and the use of public urban space by residents of urban neighbourhoods. Urbani Izziv, 25(1) pp. 107-125.DOI: 10.5379/urbani-izziv-en-2014-25-01-003

Karuppannan, S., \& Sivam, A. (2013). Comparative analysis of utilisation of open space at neighbourhood level in three Asian cities: singapore, delhi and kuala lumpur. Urban Design International Vol. 18, 2, 145-164.

Malek, N. A., Mariapan, M., \& Rahman, N. I. A. (2015). Community participation in quality assessment for green open spaces in Malaysia. Procedia - Social and Behavioral Sciences 168 (2015) $219-228$.

Nasution, Achmad Delianur, Zahrah, Wahyuni (2012). Public open space privatization and quality of life, case study Merdeka Square Medan. Procedia - Social and Behavioral Sciences 36 (2012) $466-475$

Nasution, Achmad Delianur, Zahrah, Wahyuni (2012). Neighborhood open space and quality of life in low-income settlement: Rahmadsyah Square case study, medan, Indonesia. Proceedings HABITechno International Seminar - Innovation Housing and Settlement Technology. Bandung : ITB

Nasution, Achmad Delianur, Zahrah, Wahyuni (2014). Community perception on public open space and quality of life in Medan, Indonesia. Procedia - Social and Behavioral Sciences $153(2014) 585-594$

Ngesan, M. R., \& Zubir, S. S. (2015). Place identity of nighttime urban public park in Shah Alam and Putrajaya. Procedia - Social and Behavioral Sciences 170 (2015) 452-462.

PPS - Project for Public Spaces (2000) How to Turn a Place Around: A Handbook of Creating Successful Public Spaces, New York: Project For Public Space

Sakip, S. T. M., Akhir, N. M., \& Omar, S. S. (2015). Determinant factors of successful public parks in Malaysia. Procedia - Social and Behavioral Sciences 170 (2015) 422-432.

Whyte, W. H. (1980). The Social Life of Small Urban Spaces. The Conservation Foundation, Washington, D.C.

Zakariya, K., Harun, N. Z., \& Mansor, M. (2014). Spatial characteristics of urban square and sociability: a riview of the City Square, Melbourne. Procedia - Social and Behavioral Sciences 153 (2014) 678-688. 